\title{
Regional School Library Coordinators' Visions of Quality School Library Programs and Their Role in Helping to Achieve Them
}

\author{
Jeanne BUCKLEY, \\ Divisional Program Teacher-Librarian, \\ York Catholic District School Board, \\ Canada
}

\begin{abstract}
A school library coordinator is a position of central leadership for district school boards. The visions of six Canadian school library coordinators about aspects of strong school library programs, and how their role helps achieve them are investigated in this qualitative interview-based study. Results showed that coordinators felt their roles of providing professional development and advocating for school libraries help create school library programs that improve student achievement. For the future, they envisioned a greater role for school libraries in education, with greater collaboration between school library, technology, literacy, and public library circles. A need for greater provincial government support for school libraries was identified. This study explored the values and hopes of school library leaders in Canada, and indicated that a coordinator can do much to support districts' school libraries and media centers.
\end{abstract}

\section{Introduction}

During my first two years as a teacher-librarian, I had the benefit of a lot of support from the central office of my school board. In my first year, there were training sessions at the Education Centre, central cataloguing services, a large central library, and a Supervisor of Library Services (school library coordinator) who visited my school several times during the year. This support was very needed as I was, at that time, unqualified. In my second year, I changed school boards. In this board, there were inservices at the board level on curriculum design, computer software, advocacy, and various other library-related topics. This board did not have a central library, but contracted use of another board's central video collection. If I had any difficulties, the school library coordinator and the automation specialist were only a phone call away. Now qualified, I still had a lot to learn about teaching in the school library and about local automation software and I benefited from the support given by the central school library staff, in particular the school library coordinator.

At the end of my second year, the library consultant resigned for personal reasons and, to my dismay, was never replaced. It has been more than three years since this resignation, and I have had the opportunity to observe the differences in services and support available in a board without a school library coordinator. These observations have led to a strong personal interest in learning more about the school library coordinator's role.

Currently, the teacher-librarian association members in my board have picked up some of the duties previously carried out by the school library coordinator. Other board-level employees have been assigned other duties. But, many of the school library 
coordinator's duties are not being done. This led me to wonder, in boards where school library coordinators exist, what exactly is their role and which duties of theirs do they feel are most important?

It is with these questions in mind that I began my research into the role of school library coordinators.

\section{Statement of the Problem}

In Canada, there is no consistency to school board staffing related to libraries, certainly not to levels of school-based teacher-librarians and library technicians, and definitely not to central library leadership positions, such as a school library coordinator. Why do some school districts, regardless of size, employ school library coordinators while others do not? Are they not perceived as valuable?

Just what is the value of employing a school library coordinator in a school board? Presumably, contributing to the development of quality school library programs would be a value. What do people in school library coordinator positions see as their role in contributing to quality school library programs in their district?

\section{Purpose}

The purpose of this qualitative research was to attempt to explore some of the questions asked above. Specifically the questions I addressed were:

- What themes emerge when school library coordinators discuss their role and their most important duties?

- What do school library coordinators envision as important in quality school library programs?

- How do school library coordinators see their role as helping to contribute to quality school library programs in existing conditions and in ideal conditions?

It was hoped that the information generated by this research would help to paint a picture of existing contributions of school library coordinators to quality school library programs in Canada. In addition, I hope this research would provide a staring point for understanding the school library coordinator role. I also hoped that this research will assist those in school library coordinator positions and those who are considering the implementation of such a position in their school board.

\section{Definitions}

Teacher-librarian: "A professional teacher with a minimum of two years of successful classroom experience and additional qualifications in the selection, management and utilization of learning resources, who manages the school library and works with other teachers to design and implement resource-based instructional programs” (Asselin, Branch \& Oberg, 2003, p. 84).

School Library Coordinator: a professional teacher, librarian, or teacher-librarian who is employed by a district school board or provincial education authority in a salaried position of leadership over school libraries. This position would include guiding the school level library staff in implementing their library program. Normally a school library coordinator would have advanced school-library-related qualifications and experience as a teacher-librarian. This definition would not normally include 
elected presidents of teacher-librarian associations, or volunteer mentors of teacherlibrarians. Additionally, not included in this definition would be persons who solely provide centralized cataloguing or other technical support for school libraries, or persons in charge of central libraries whose job descriptions do not include guiding/training school library staff. It is important to note that literature in the field uses many other titles/terms for school library coordinators including: District Library Coordinator, Supervisor of School Libraries, Board Library Consultant, and Library Media Director.

\section{Review of the Literature}

Discussion of the role, responsibilities, and value of a school library coordinator has been almost non-existent in most journals and publications over the last 15 years, however, an exhaustive search has turned-up research and professional works that will inform the research. This section will explore what the literature has to say about the roles and responsibilities, qualification and experience, and value of a school library coordinator.

\section{Roles and Responsibilities}

An examination of available research revealed contradictions. Andwood (1984) conducted research into the leadership role of a library media director (school library coordinator) and concluded that teacher-librarians' perceptions of the actual duties carried out and their expectations of the role of the library media director do not always match. In other words, what the teacher-librarians felt should be the role of the library media director, was not always what they saw. Coulter's (1990) study, which compared reported duties of district library media directors with those in the document, Information Power: Guidelines for School Library Media Programs (AASL \& AECT. 1988), supports this finding.

However, Krentz's (1986) Wisconsin-based study of the perceptions of library media director's, principal's, and school library media specialist's perceptions of the competencies (roles) of library media directors found some surprising results. In contrast to Andwood's results, this survey found that all three groups were in agreement as to the competencies measured.

Nelson's (1988) research gave a good picture of the actual role (as opposed to the ideal role) of a school library coordinator in the United States. The data showed that the position was not full-time, not supervisory, and in the overall administrative hierarchy "generally occupied subordinate, non-administrative positions" (p. 46).

An examination of the available Canadian literature revealed a strong list of recommended responsibilities for school library coordinators. Asselin, Branch, and Oberg (2003) state that a District Library Coordinator should act "as an advocate for information literacy and instructional technologies", help "coordinate the integration of information literacy outcomes", and "may also be involved in developing and maintaining a district resource collection that supports teaching a learning” (2003, p. 54). Other responsibilities are summarized below:

- $\quad$ Administering board-wide library budget

- $\quad$ Keeping current with standards

- $\quad$ Helping administers select, supervise, and evaluate library staff 
- $\quad$ Helping teacher-librarians develop successful library programs

- $\quad$ Supervising central purchasing and cataloging of resources

- $\quad$ Serving on curriculum and technology committees

- $\quad$ Reporting to senior administration on library matters

- $\quad$ Assisting with professional development related to information literacy and communication technologies

- $\quad$ Participating in professional organizations and continuing education

- $\quad$ Serving as school library liaison in the community

- $\quad$ Educating parents and others about the information literacy program

- $\quad$ Helping to plan construction and renovation of library facilities

(Asselin et al., 2003, p. 55)

A detailed description of the role of a district-level coordinator for school libraries is also provided in a 40-year-old publication of the Saskatchewan Association of School Librarians (SASL, 1964), which uses the term "supervisor of libraries" (p. 21). The roles of this supervisor, as described in the document, are summarized below.

- $\quad$ Work with the provincial department of education to ensure adequate financing

- $\quad$ Sets up standards common to all schools

- $\quad$ Evaluate the library program and report to senior administrators

- $\quad$ Providing democratic leadership and guidance

- $\quad$ Helping schools organize services that meet the needs of the curriculum

- $\quad$ Make frequent contact with individual schools

- $\quad$ Shares responsibility for the total educational program

- $\quad$ Provides in-service for untrained teacher-librarians

- $\quad$ Support the school library association

- $\quad$ Maintain good relationships with community library services

- $\quad$ Interprets the role of the library to administrators

- $\quad$ Promote the library program to the general public

Williams and Buddy (2001) suggest that coordinators need to "nurture new

library media specialists" in order to retain them and to assist them in "their support of and implementation of the goals of the school system” (p. 251) and describes a program designed to do so. Support of new teacher-librarians is one important service that may be lost when a school library coordinator position disappears from a district (Lindsay, 2004). In Lindsay's experience, also lost was the service of negotiating board-wide purchases, which, in the past, had resulted in significant cost-savings (Lindsay, 2004).

The School Library Administrators of Manitoba (2000), in an interesting perspective, outline the role of the division library media centres, rather than the role of a school library coordinator. One of the roles of the centre is "educational leadership" (p. 10). Specific duties related to educational leadership include: determining selection policies, serving on curriculum committees, promoting division and province-wide policies and initiatives, organizing staff development workshops, and facilitating resource sharing (SLAM, 2000, p. 10). Other roles attributed to the division library media centre (and presumably its staff) are providing "cost effective ways to acquire learning resources", reinforcing "the concept of equitable access", providing a "union catalogue”, and designing and producing learning resources (p. 11). A similar document (Hersak, 2004), outlining the role of District Library Media Centres and their staffs, also 
focuses on the centre, rather than the staff within. This document adds communication and publication as well as archival responsibilities (Hersak, 2004, para. 11-12, 18). In these documents, while the focus seems to be on the institutions rather than the persons, clearly the personnel of the institutions are the ones carrying out much of the role as defined.

An interview with a school library coordinator revealed that not all school library coordinator positions have easily defined roles. They can have a variety of responsibilities not related to school libraries (Buckley, 2004). Yet, in one school board, the central school-library related staffing was more than full time, with a districtwide coordinator as well as 4 instructional leaders and two centrally-assigned teacherlibrarians to support her (Rosenfeld, Thomas, and Teodosio, 2004, para. 2).

\section{Qualifications and Experience}

The literature indicates that a combination of different qualifications and background experience are both recommended and typical in a person in a school library coordinator position. The Saskatchewan Association of School Librarians document suggests that a good "supervisor of school libraries" has "professional library training, but also professional teacher preparation and actual experience as a school librarian” (SASL, 1964, p. 21). In his dissertation, Nelson (1988) gave a good descriptive picture of the typical district library media director (school library coordinator) in the United States. The data showed that "the majority of media directors were females who served an average of 38 schools" had "a Master's Degree in Instructional Media or Library Science and ... 5 years of experience as a classroom teacher, 6 years experience as a building level library media specialist, and 10 years experience as a district library media director" (p. 45). Recent Canadian school library standards do not set out qualifications for a school library coordinator except in use of the phrase "a school library professional” (Asselin et al., 2003, p. 54) to describe the person.

\section{Value}

Several publications stress the value of having school district leadership. In Achieving Information Literacy: Standards for School Library Programs in Canada, Asselin et al. (2003) state that "a collaborative team of educators", including "a qualified teacher-librarian, classroom teachers, the school administrator, curriculum consultants, a coordinator for the district library, and the superintendent of the school district ... is required to achieve information literacy and successful school library programs and services” (p. 52). Doiron and Davies (1988) state that a more positive student performance on "outcome measures of literacy, information handling and use" is only possible "when there is recognition that the library program is a partnership ... of the teacher-librarian and the classroom teacher, supported by school district leadership"(p. ix). In Britain, while the overall framework for school library provision appears quite different from North America, a similar need for leadership positions is expressed by Campbell (1989). The Saskatchewan Association of School Librarians (1964) states "competent supervision helps reinforce "every individual or local effort to provide better library programmes in the school” (p. 21).

The above publications state but do not substantiate a 'need' for a central leadership position by giving examples of the benefits a person in such a role can provide. Generally research into the value of a school library coordinator shows mixed 
or inconclusive results. For example, Eberhard (1975) found that media personnel with a district school media director were more involved in six service areas than those without a district school media director (p. 172). She also found that in centers with a district school media director, more professional contact hours were provided in school libraries, but in centers without a district school media director, more clerical contact hours were provided and the school libraries were open more hours in total (p. 176-7). Eberhard concluded that, "the presence of a District School Media Director does appear to affect positively library media programs and services” (p. 178). Coleman (1982) reported similar findings in a study of teacher-librarians' perceptions of library programs. He found higher implementation ratings of program component areas for teacher-librarians who had a district-level school library administrator.

Zsiray's (1986) study of elementary school library staffing patterns revealed different conclusions. Zsiray compared the professional activities in school library media centers with four different staffing models. He found that "district-level library media specialist support for building-level library media specialists did not contribute to higher levels of professional performance" (p. x) and that, "the contributions made by certified building-level elementary school library media specialists were only marginally different in most cases from programs offered by elementary school library media aides" (p. 136). However, these results might be due to understaffing of libraries (in this case, staffed with either a library media specialists or a library media aide, but not both), which might minimize the effect a district-level media specialist could have on the quality of the programs as the building-level staff are unable to do more than the minimum to keep the library operating.

Miller and Moran (1983), in their questionnaire on library expenditures showed that "schools without district coordinators [had] more money per pupil to spend on resources” (p. 110). Schools with district media coordinators included a larger AV collection, higher clerical assistance, and higher salaries for school media specialists (p. 110-111). However, the survey did not collect information on the existence or size of a central library in the district. Theoretically, diversion of funds from schools to a central library collection might explain why expenditures in these schools were lower. However, having a central library means access to more resources for the students and staff in a school.

None of these studies give conclusive evidence for the value of having a school library coordinator. These examples of benefits primarily manifest themselves in "assistance": assistance for teacher-librarians with their responsibilities and assistance for administrators with theirs.

With so many of the described roles of such a position being helping or shared responsibilities, able to be carried out by someone in another position, be it teacherlibrarian, school-based administrator, or senior administrator, it is not surprising that the role and value of the position is difficult to determine and varies so much from jurisdiction to jurisdiction. Even in jurisdictions that seemed to understand and value the role of the school library coordinator this did not always translate into keeping such a position. In the course of Krentz' (1986) research, “it was learned [that] several fulltime library media directors retired or resigned and those school districts decided not to refill the position" (p. 177). The author suggested that research as to why some school districts did not feel the position of library media director was "crucial to implementing their library media program" (p. 177) would be interesting to the library media community. 
In fact, these school districts would not be alone. A recent survey of 637 library media specialists revealed that more than half were from jurisdictions that "had no district-level director of library media centers” (Miller \& Shontz, 2001, p. 51).

\section{Challenges to Research in this Area}

A challenge to defining the role and value of a district-level coordinator of school libraries is the ambiguity and inconsistency of terminology and job-titles related to the position. The use of a consistent term for this role is complicated by the fact that titles for the role vary from district to district. The library leadership role may be combined with other responsibilities into one position and a new title created to reflect the combined duties. This confusion is not limited to the North American context. Alasdair Campbell (1989) comments on a similar nomenclature confusion in Britain. Another complicating factor is the titles of school-based professional staff in the library. The terms 'teacher-librarian' and 'school library media specialist' are common in most parts of North America, but some use the term "school library media coordinator" or "library media coordinator" (Fowler, 1992) to refer to these school-based professionals. Research into school library coordinators will continue to be hampered by the fact that the position has to be defined by its responsibilities, rather than by its title.

A second challenge is the difficulty in identifying research subjects. The lack of consistency in job-title, as well as the combining of different responsibilities within one role, makes it difficult to determine who exactly in a particular district is in charge of libraries. As well, responsibilities for library aspects at the board level may be divided among several different people. A computer technology consultant may be responsible for library automation, a curriculum consultant may be responsible for the instructional program, and a third consultant may be responsible for collection development initiatives. To further complicate matters, duties and responsibilities may be shuffled from year-to-year, or when retirements and staffing changes occur.

Titles change from district-to-district and from year-to-year, and the collection of responsibilities carried out by such a person do as well. These staffing realities make research data collection challenging.

\section{Themes Emerging From the Research and Literature}

After examining nearly 40 years of research and literature on the subject of school library coordinators, several facts became evident.

- $\quad$ There has not been a lot of research or literature published on this subject, likely due to the challenges mentioned above as well as the fact that there is a relatively small audience for information on this subject.

- $\quad$ The quantitative research that has been completed shows conflicting and/or inconclusive results.

- $\quad$ Many school systems do not have school library coordinators, indicating that at the system level, decision-makers do not generally agree on the value of the position.

- $\quad$ There are many possible roles and responsibilities for such a position, but they vary greatly from jurisdiction to jurisdiction.

It is on this basis that I began my research to help describe the similarities in the roles and opinions of school library coordinators from across Canada. There is a definite need for research of this type because, although articles and other publications exist that describe the role or value of a school library coordinator, the majority of 
actual educational research into this area has been of a quantitative nature and completed in an American context. Therefore, this qualitative study based in Canada will help to expand existing knowledge in this area.

\section{Setting}

\section{Method}

The study took place in Canada following decades of cuts to school libraries and to school library coordinator positions. Canada is a country separated into 10 provinces, each with their own provincial education systems, and 3 territories with federal education systems. Typically each province has many school boards of varying sizes which provide guidance and services for the schools. School boards are usually determined on geographic, religious, and language basis. There is a public nondenominational school board system and a Separate (usually Catholic) school board system protected by the constitution.

\section{Participants}

The participants in the study were all school library coordinators. Each was from a different province of Canada. The names of persons in school library coordinator positions were solicited from various members of the Canadian Association for School Libraries. A letter was sent to seven school library coordinators requesting their participation in the study. Six responded affirmatively.

\section{Procedures}

Between September of 2004 and January of 2005 telephone interviews lasting between 25 minutes and 55 minutes were conducted with the six participants. The interviews were arranged at the participants' convenience and were tape-recorded. All participants were asked the same 9 questions except, on occasion, when a participant's answer to a question required clarification, or when a participant's answer clearly included the answer to a subsequent question. The questions were designed to explore the role of the participants when they were school library coordinators as well as their vision of what constitutes a quality school library program. Responses were generally expansive.

The recordings were later transcribed, coded, and analysed by the researcher for trends and themes in the participants' responses.

\section{Findings}

\section{Participants’ Background}

The participants (identified A through F) in this study represented six different provinces, and six school boards ranging in size from 10 schools to over 100 schools. One was from a publicly-funded Catholic school board and five were from public school boards. Three were current library coordinators and three were former school library coordinators. All had a minimum of 2 years in their position, although most had more, as many as 17. 
All participants had taken courses in school librarianship. Two had Master's degrees in library science. Three had advanced degrees in education and/or school librarianship.

All had more than 3 years experience as a teacher-librarian prior to becoming a school library coordinator; two had more than 10 years of teacher-librarian experience. All were classroom teachers prior to becoming teacher-librarians (and later library coordinators), some with as many as 14 years of classroom experience. As one school library coordinator said,

I had worked at every level, both in the classroom and in school libraries. ... When I came into that position, I think, I was able to relate to the people I was talking to, whether I was talking to a classroom teacher or whether I was talking to a teacherlibrarian. (Participant C).

Four participants had experience teaching at the university level in courses for teacher-librarians. Three had held more than one school library related leadership position in their careers.

Four were hired into positions within their school board after demonstrating leadership potential. Four were hired into positions outside of their school board. All had experience on at least one library-related committee or membership in at least one school library association. Some had experience in other positions at the board level which may have contributed to their skills set. As one put it, "a lot of people were good teacher-librarians, maybe ... better than I was, but they didn't have the leadership to look at a more holistic approach to the school library ... I've always managed to, in some ways, be able to assess what the current needs are” (Participant D).

\section{Participant Visions of Quality School Library Programs}

All six of the participants mentioned a teacher-librarian as being of primary importance in a quality school library program. Quotes that illustrate the importance of this fact to each school library coordinator include:

"a well-credentialed, and well-experienced, and qualified teacherlibrarian is the turning point of a strong program"(Participant B), "a teacherlibrarian with a personality of support, collegiality, well-trained, and with a good knowledge for the curriculum and learning strategies.”(Participant D) "a qualified, trained, certified ... teacher-librarian in place in the school for an adequate amount of time. With the placement of that person I feel confidant that [other desired aspects of a quality school library program] will follow" (Participant F) and "You won't have a school library program unless you have a teacher-librarian” (Participant E).

The participants felt that a qualified teacher-librarian was necessary to a quality school library program because they would have skills in the area of the program each participant felt was most important. These included "knowledge of resources and an ability to promote them", (Participant D) "research and inquiry methods" (Participant E), "collaborating with the teacher"(Participant A), the "supporting leader" role of the teacher-librarian (Participant B), or "the teaching role of the teacher-librarian" (Participant C). Participant F did not identify one single area of the program as most important, but mentioned that "budget", “instruction”, “collection”, “technology”, 
"collaboration and integration", would follow the placement of a "qualified, trained" teacher-librarian.

The three participants who did not mention collaborative or cooperative teaching as the primary area of the library program mentioned it as the second most important area. Participant D mentioned knowledge of instructional strategies and curriculum as a skill needed by the teacher-librarian.

Other qualities of a good teacher-librarian included having "leadership" and "vision" and a "helpful personality" (Participant D). Also, four participants mentioned skills in collection development either directly or indirectly, with phrases such as "a relevant collection," (Participant F) with both "print and non-print resources" (Participant B) to which the students had "equitable" and "broad access" (Participant D).

Four participants mentioned technology, saying that technology was necessary to link the library with the classrooms and the outside world and that it should be integrated. Participant B mentioned specific technologies that should be in the library facilities: a data projector, Internet access, and personal listening and viewing centres.

Participant E mentioned "integration of literature into the curriculum" and that emphasizing "an understanding of culture" with students as important to a library program. Participant B mentioned that the library had to be well funded, centrally located, flexibly scheduled, and "backed-up by a policy and procedure at the board and [provincial government] level". Participant F said that "support staff to enable the teacher librarian to do the collaboration required with the classroom teachers" was a characteristic of a quality school library program. It was also mentioned that teacherlibrarians need to be working directly with students (Participant A).

\section{Participant Roles}

It should be noted that several participants who had been in more than one school library coordinator position or who had been in the position for a number of years reported different duties at different times in their careers. One said that her job "has evolved over the years, because it was just library at the beginning, and then ... information technologies, and then ... information literacy" (Participant B). So, not all of the duties reported below may be current duties of the participants, but at some time all were.

Advocacy for school libraries and school library staffing was mentioned by all of the participants as something they did within their role as school library coordinator. Participants C and B felt it was their most important role. Specifically, advocacy at the board level was mentioned by four participants, and advocacy to the parents and the public was mentioned by three participants. Only two participants mentioned advocacy at the government level as a role of their position. It should be noted that all six of the participants were involved in provincial and/or national level associations for teacherlibrarians. It may be that they felt that advocating school libraries at the government level was part of the responsibilities of these associations, but not of their job.

Supporting and training teacher-librarians and library technicians or assistants, especially new ones, was mentioned by all participants as something they did in their positions. Participant E felt this was the key of a school library coordinator. As well, three mentioned support for new teacher-librarians, on a one-on-one basis, as an important part of their role, especially during times of high of staffing turnover. Overall, leading the teacher-librarians in implementing desired aspects of a quality school library 
program was seen by the participants as part of their role. Some chose to do this by leading by example, others by producing publications for teacher-librarians, others through training or direct guidance. As well as providing workshops for library staff, two participants also collaborated with other board level staff to deliver workshops for teachers.

Five of the six participants mentioned collection development support for school-level teacher-librarians as part of their role. Two specifically mentioned video purchasing as an area they support. Two provide support for weeding of school libraries. One, who is in a small school board, actually does a lot of bulk ordering for the school board, including libraries.

Liaising with public libraries and the faculties of education at the universities were reported duties of two of the participants.

In the area of technology, three participants felt it was their role to stay current with emerging technologies. Leading automation initiatives was the responsibility of three participants as well. Participant D negotiated board-wide contracts for various resources and one supported purchasing of software and technology for the board.

Communication was a duty reported by four of the participants. This duty was carried out in different ways. Two reported participating in a teacher-librarian listserv. One published a journal for teacher-librarians. Two reported that keeping teacherlibrarians and administrators up-to-date on current school library research was one of their duties; Participant F felt it was her most important duty and published a monthly newsletter, which outlined new advancements in the field. Participant A reported publishing resources to support school libraries, on her own, or in conjunction with other teacher-librarians as the most effective aspect of her role as school library coordinator.

Four of the school library coordinators also managed central libraries for their boards as part of their duties. The central library staffs ranged from 5 to 28 people. The central library staff circulated central resources and, in some cases, did part or all of the cataloguing for their boards. Participant B occasionally arranged for guest speakers to address teachers in the central library facilities.

In two cases where there was a central library, the school library coordinator was responsible for evaluating its staff. Two participants also reported evaluating schoollevel non-professional staff. Only Participant D reported evaluating teacher-librarians as a duty. Three, however, did report evaluation of the school library program (but not staff) as a duty. Two reported being consulted on library staff hiring decisions.

Two participants reported that general consulting on school libraries at the schools in their board was one of their duties, and two reported that they were consulted on the design of new school libraries and the remodelling of existing ones.

Several participants reported duties that were not mentioned by other participants. Policy development was the responsibility of one participant. She helped to get statements regarding school libraries written into the provincial education curriculum, and felt this was her most effective duty. She was also part of policy meetings in other areas such as developing "acceptable use policies". Another participant had the responsibility of archiving student records. She also made an annual plan for her activities and reported on it monthly to her superiors. 


\section{Participant Ideal Roles}

All of the participants reported being, at some point in their careers, hampered in what they could do to support school libraries by conditions beyond their control, most notably a lack of sufficient library staffing at the school level. None felt the level of staffing in school libraries in their area was sufficient.

When asked what they would like to do to support quality school library programs, their answers varied. All would like to see more library staffing. This was mentioned either as a goal of theirs, or as a requirement for them to carry out other goals. When increasing staffing was a personal goal, access to decision-makers in their board was what was needed.

Three imagined themselves in an ideal world with sufficient staffing and stated what they would like to be able to do then. Participant D would like to be able to spend "more time working directly with teacher-librarians" and would like to see better quality resources in the schools. Participant A would like to give a half-day workshop for teacher-librarians each month. Participant B would like to be able to say, "I am implementing an education ministry [provincial government] library policy”, as this would give libraries a higher priority in the board.

All participants mentioned the importance of a ministry policy and provincial government support for school libraries. Participant A also mentioned a need for provincially funded databases, and library-related curriculum topics (plagiarism, copyright, media awareness, and so on) mandated in the curriculum. This echoes the voices of several participants who, at various points in their interviews, expressed a need for provincial government support for libraries and library-related curriculum being written into education documents. Four mentioned a need for specific funding for school libraries from the provincial governments.

\section{Participant Visions of the Future of School Library Programs}

More general visions or hopes for school libraries in the future were described by each participant.

Participant D would like to see school libraries "taking a bigger role in education". Participant B said similarly, "I would like to see the school library become the heart of the school program in the school community". Participant E would like to get rid of the stereotype that teacher librarians just "sign out books" and would like to bring the library community together (public libraries and school libraries working toward common goals).

Participant F would like to see a greater implementation of existing curriculum "which is inquiry-based ... to develop in students the skill of learning how to learn" including "ethical information use" and the "use of a variety of formats of information".

Also mentioned as a desired direction for the future was the implementation of the standards outlined in Achieving Information Literacy (Asselin et al., 2003) in a planned way because "we are not going to be able to move from where we are to where we need to be in one fell swoop" (Participant F). The document has standards for staffing, funding, collection size, and library program (Asselin et al., 2003). This kind of planned, gradual change was also mentioned by participant $\mathrm{C}$ who wanted a guaranteed staffing model "so that people can move forward".

Participant B mentioned a convergence between the information technology world and the library world as something that "has to happen" before school libraries can start being revitalized. 


\section{Limitations}

This study was limited by the small number of participants. Because this study was undertaken to fulfill the requirements of a three-credit course at the University of Alberta by a single researcher, it was determined that five to seven interviews were all that could reasonably be completed and transcribed in the time allotted to this course. While attempts were made to contact persons in school library coordinator in other provinces of Canada, persons who were or had been in school library coordinator positions could only be located in six provinces.

This study was also limited by the fact that three of the participants were no longer in school library coordinator positions at the time of the interview. It should be noted that all three of these participants were still involved in school libraries. One had retired but was continuing to consult for various organizations on school library issues. The other two were teacher-librarians.

\section{Themes Arising from the Interviews}

Analysis of the interviews reveals an underlying frustration of participants. They are frustrated by limited staffing and funding of school libraries and the tenuousness of their positions, which they feel are vital for achieving quality school library programs. Participant B expressed this by saying "I stay here, partly because I'm fearful that they might not replace me. We've seen that happen in so many boards that when the longstanding [school library coordinators] retire, they don't necessarily replace them".

The participants believed strongly in school libraries and felt teacher-librarians should too. "The whole idea of advocacy and political action - if you are going to be a teacher-librarian, you have to buy into it”(Participant F). All of the participants had made advocacy part of their role.

\section{Discussion, Implications, and Recommendations}

The current and former school library coordinators who participated in this study were highly experienced as both teachers and teacher-librarians. They had been working in the fields of education and teacher-librarianship for long enough to have developed an understanding of what is important. Even though they each represent a different province with different curricula and educational systems, their visions of what makes or could make quality school library programs have many common themes. It is important to recognize these commonalities, but also to look at what makes their visions different, as in these differences may lay opportunities to expand our own visions for the future.

The school library coordinators recognized that existing school library standards and related curriculum were often not being implemented due to insufficient staffing in school libraries in Canada. Their call for government attention to school libraries is a call for governments to create an environment where school library programs can move forward to provide support for students and teachers in their educational goals.

It may be that the greater cooperation between school library, public library, information technology, and literacy circles, recommended by participants in this study, may indeed lead to a synergistic relationship that works for the betterment of education 
in Canada. School library coordinators are in a leadership position that allows them to direct school libraries down a path to fulfill their visions for the future of quality school library programs. Their continued leadership is important for Canadian school libraries.

To help achieve this, I would like to make three recommendations:

- Most school boards should have in place at least one school library coordinator

- School library coordinators should work to make themselves indispensable to the larger school board

- $\quad$ Advocacy by school library coordinators should continue

\section{School Library Coordinators Positions in Most School Boards}

Large and medium-sized school boards or school boards which have a significant proportion of less-trained or inexperienced teacher-librarians should employ a school library coordinator, as should school boards that do not staff school libraries at recommended levels. A school library coordinator will provide professional development and support for new teacher-librarians and those without a lot of previous training. In poor staffing situations, a school library coordinator can help teacherlibrarians make the most of their limited time in the libraries, by coordinating the efforts of the teacher-librarians in the board so that they can share information and workload in areas such as lesson planning and resource selection. As well, a school library coordinator can eliminate duplication of efforts by arranging and negotiating boardwide deals for electronic databases, union catalogues, and automation software for the teacher-librarians. This kind of activity may also result in significant cost-savings for a school board.

In medium and large-sized school boards, the amount of teacher-librarian time and library budget money that could be saved by employing a school library coordinator would be significant, and could easily justify the hiring of a full time school library coordinator whose salary might only represent a small fraction of the overall school library budget. Smaller boards could justify having a school library coordinator by capitalizing on the specific skills and training of a school library coordinator to support the administration and teachers in their duties, not just the library staff.

A school library coordinator might not be necessary in very small school boards with less than 10 schools, provided that each has in place library staffing that meets the CSLA/ATLC standards including fully qualified teacher-librarians and adequate clerical and technical support (Asselin et al., 2003). In such cases, provision of time for the handful of teacher-librarians to meet regularly with each other and with a board-level consultant or superintendent who oversees school libraries may be sufficient.

\section{Indispensability}

This study revealed several ways that participants directly supported board employees outside of the school libraries. Two of the coordinators in this study provided professional development workshops for classroom teachers on topics such as resourcebased instruction and information literacy. One supported teachers and principals who made the classroom teaching resource selections for their schools by evaluating and recommending textbooks and classroom instructional materials. A third read many educational journals (including, but not limited to school library related journals) and helped administrators keep up-to-date on advancements in education (and school libraries) through a monthly newsletter. 
Considering the fear that exists that school library coordinator positions may be cut, it might be prudent of school library coordinators even in medium and large boards to look for similar ways that their skills could benefit the larger school system. A school library coordinator who does that could be seen as indispensable even in a system that, unfortunately, doesn't see school libraries that way.

\section{Advocacy}

Due to the cuts to educational funding across the country, all of the participants had experienced a decline in school library staffing situations at some point in their careers. They had worked in situations where their own position was tenuous, or where the positions of the teacher-librarians with whom they worked were being cut or eliminated. These participants understood the important advocacy work that must be done before anything else. It is important to help teacher-librarians develop collections and to improve programs, but if the teacher-librarian positions are eliminated, all of the work done to support them becomes meaningless. Advocacy is an important part of a school library coordinator's position, because one of the best ways to support teacherlibrarians is to help them have more time to work with students and larger budgets to develop their collections.

\section{Future Research}

This study only looked at six school library coordinators from across an educationally diverse country. Future research that looks more specifically at school library coordinators within one province may help illustrate more clearly the role of school library coordinators in that province.

Since there are many school boards in Canada that do not have school library coordinators, future research that compares the situations in school libraries in these boards with the situations in school libraries in boards where there are school library coordinators may help to illuminate the value of having a school library coordinator. As well, research that describes the changes to the quality of school library programs following the creation of a school library coordinator position in a board that has not had one previously may also help illustrate the value of school library coordinators.

The school library coordinators in this study all worked in boards where less than recommended levels of library staffing exist. It may be true that in order for school library coordinators to be able to properly support the school library programs, building level staffing of both teacher-librarians and administrative staff members needs to be sufficient for persons in both roles to be able to carry out all of the duties assigned to them, not just the minimum to keep the library running. Perhaps further research should be carried out in areas where higher levels of staffing are provided.

\section{Conclusion}

When school library coordinators discuss their role, three themes emerge as important to their role: advocacy for school libraries, support for library staff, and communication between education stakeholders.

School library coordinators feel that qualified teacher-librarians who have an understanding of how the library best supports student achievement are of greatest importance in quality school library programs. Also important are adequate levels of technology, library support staffing and time to enable teacher-librarians to implement the best school library programs possible. 
School library coordinators see themselves currently contributing to quality school library programs through advocacy to improve school library staffing and by supporting the as-yet-insufficiently staffed teacher-librarians in their survival. In an ideal world, they would like to do more to help teacher-librarians implement school library programs that meet and exceed the qualities and conditions that the existing educational research and their own experience tell them best support student achievement.

Considering all that school library coordinators do or could do to support school libraries in improving student achievement, people in school boards without school library coordinators should be advocating for the creation of such a position. Existing school library coordinator positions should be maintained and school board officials should consider expanding school library coordinator positions and school library staffing generally in their boards, so that the best school library programs possible can be obtained. 


\section{Appendix A}

\section{Sample Questions Asked of Participants in the Study}

1. Please tell me a bit about your background in the field, how you got to this position, and what your job involves.

2. What do you see as of primary importance in a quality school library program?

3. In your opinion, what are other characteristics of a quality school library program?

4. What do you see as your current role in helping to achieve quality school library programs in your region?

5. What of duties of yours do you feel are most effective in helping to achieve quality school library programs in your region?

6. In an ideal world, what would you like to be able to do to help achieve quality school library programs?

7. In your opinion, what would help you to do this?

8. In which directions would you like to see school library programs moving in the future?

9. Are there copies of a published job description for your job or any other documentation related to any questions above that you wish to submit for clarification or support of one of your answers? 


\section{Appendix B}

\section{Information Letter Sent to Participants}

Dear

This letter is requesting your participation in a study I am completing. This study will examine participants' visions for quality school libraries and their perceived contributions that they do or could make toward achieving that vision.

I am currently working to complete the requirements of a Master of Education degree, with a school library focus, through the University of Alberta, and the study will form part of my final "capping" paper. As such, it may be published and/or presented at a conference. My research project will examine regional school library coordinators' visions of exceptional school library programs. Participants will be asked to agree to a personal telephone interview of approximately 45 minutes, to discuss their visions. The interview would be scheduled at the participant's convenience, during the months of August, September, and October, 2004. Participants will also be asked if they wish to submit documents (such as job descriptions, if they exist) which may help to clarify their answers, but this is also strictly voluntary.

I would value your participation. If you consent to be involved in this study, your anonymity will be maintained. You would be free to withdraw at any time. If you decide to withdraw your participation later in the term, any data collected from you would be withdrawn from the study at that time. A tape recorder will be used to record our telephone conversation and I will transcribe the tapes. I will use a pseudonym to represent you in all work that is written about the study and I will keep your interview tape and transcripts in a locked filing cabinet in my office for a minimum of five years following completion of the research.

The attached consent form will explain this study more fully. If you have any further questions about the study, please feel free to contact me at (416) 440-0251, my university advisor, Dr. Jennifer Branch, at (780) 492-0863, or the Chair of the Department of Elementary Education, Dr. Dianne Oberg, at (780) 492-2267. Please complete the attached consent form, to indicate your decision. If you are willing to participate, please return the consent form to me. Thank you for considering this request.

Yours sincerely,

Jeanne Buckley, Teacher-Librarian, York Catholic District School Board jeannebuckley2@yahoo.ca 


\section{References}

American Association of School Librarians \& Association for Educational Communications and Technology. (1988). Information power: Guidelines for school library media programs. Chicago: American Library Association.

Andwood, D. E. (1984). A comparison of perceptions and expectations for a central administrative leadership role of library media director as and indicator of his/her role behavior. Dissertation Abstracts International, 45 (3), 693A. (UMI No. 8408626)

Asselin, M., Branch, J.L., \& Oberg, D. (2003). Achieving information literacy: Standards for school library programs in Canada. Ottawa, ON: Canadian School Library Association and the Association for Teacher-Librarianship in Canada.

Buckley, J. (2004). The role of a library facilitator: At the buffet with Nancy Dalrymple. School Libraries in Canada, 24(2), Article 3. Retrieved February 28, 2005, from http://www.schoollibraries.ca/articles/132.aspx

Campbell, A. K. (1989). The role of the LEA inspectors/advisors in supporting school library provision. The School Librarian, 37, 92-93.

Coleman, J. G. Jr. (1982). Perceptions of the 'guiding principles in 'media programs: district and school’. Dissertation Abstracts International, 43 (7), 2206A. (UMI No. 8228611) Abstract retrieved November 8, 2003, from http://80wwwlib.umi.com.login.ezproxy.library.ualberta.ca/dissertations/fullcit/8228611

Coulter, C. M. (1990). Information power and district library media directors. Dissertation Abstracts International, 51 (8), 2716A. (UMI No. 9101094)

Doiron, R. \& Davies, J. (1998). Partners in learning: Students, teachers and the school library. Englewood, CO: Libraries Unlimited.

Eberhard, N. C. (1975). A study of Kansas elementary school library media centers with district school media directors compared to elementary school library media centers without district school media directors from 1966-1972. Dissertation Abstracts International, 35 (10), 6740A. (UMI No. 7508754)

Fowler, L. B. (1992). The power to restructure: Meeting the challenge of change for school media coordinators. North Carolina Libraries. 50(Sp. Ed.), 10-14.

Hersak, G. (2004). District Library Media Centres. School Libraries in Canada, 24(2), Article 2. Retrieved February 28, 2005, from http://www.schoollibraries.ca/articles/131.aspx 
Krentz, R. F. (1986). A study of selected competencies of full-time school district media directors as perceived by three groups of educators. Dissertation Abstracts International, 47 (12), 4219A. (UMI No. 8701854)

Lindsay (2004) Mourning the loss of the district teacher-librarian. School Libraries in Canada, 24(2), Article 6. Retrieved February 28, 2005, from http://www.schoollibraries.ca/articles/135.aspx

Miller, M. \& Moran, B. (1983). Expenditures for resources in school library media centers FY'82-'83. School Library Journal, 30(3), 105.

Miller, M.L \& Shontz, M.L. (2001). New money, old books. School Library Journal, 47(10), 50-60.

Nelson, S. (1988). The influence of the district library media supervisor on library media program development in the United States. Dissertation Abstracts International, 50 (5), 1124A. (UMI No. 9818902)

Rosenfeld, E., Thomas, P. \& Teodosio, L. (2004). Supporting school libraries: The Toronto District School Board recipe. School Libraries in Canada, 24(2), Article 7. Retrieved February 28, 2005, from http://www.schoollibraries.ca/articles/136.aspx

Saskatchewan Association of School Librarians. (1964). Proposed standards for school libraries in the province of Saskatchewan. Saskatoon, SK: Author.

School Library Administrators of Manitoba. (2000). The role of school division/district library media centers in Manitoba. MSLA Journal, 27(4), 10.

Williams, M. C. \& Buddy, J. W. (2001). Invest in new library media specialists. Journal of Education Media and Library Sciences. 38, 250-270.

Zsiray, S. W. Jr. (1986). A study of the impact of staffing patterns in elementary school library media centers on program development. Dissertation Abstracts International, 47 (7), 2352A (UMI No. 8619420)

\section{Author Note}

Jeanne Buckley is a teacher-librarian at two schools in the York Catholic District School Board located in the greater Toronto area, Canada. She also holds a Divisional Program (mentoring) position in her school board. She recently completed her Master's Degree in Education, through the Teacher-Librarianship by Distance Learning program at the University of Alberta. In her spare time, Ms. Buckley has guest edited the journal, School Libraries in Canada, and has been chair of the Ontario Library Association's Silver Birch Reading Program. 
Reproduced with permission of the copyright owner. Further reproduction prohibited without permission. 